\title{
The Role of Career Woman in Islamic Education Field in a Digital Era
}

\author{
Anisa Dwi Makrufi ${ }^{1}$ \\ Universitas Muhammadiyah Yogyakarta, Indonesia \\ Correspondence: anisadwimakrufi@fai.umy.ac.id
}

\begin{abstract}
This paper aims to analyses the role of career woman in Islam especially Islamic education in a digital, modern era. To this end, analyses on the relevant literature have been carried out. As a result, an educated family with values of Islam is the greatest favors. In a family, a woman has a central role in Islamic education. Nowadays, many women opt for a career outside their home. In Islam it is allowed, even in the recorded history, several women who became wives of the Prophet also became career women. Islam provides a strong motivation for women to run their careers in any fields in accordance with their nature and dignity without leaving their duties as ra'iyah fi baiti zaujiha (person(s) in charge of the internal problems of households). The role of a career woman in the field of Islamic education is a challenge. Considering the fact of the digital era, it is significantly important to take account of the concept of monotheism. It is the single concept referring to that of God, the Absolute Power. In this digital era, the principle of tauhid as the main one of monotheism itself is to stand for a belief that Allah, the only God, encompasses all the things. In short words, the digital age would bring people into the circumtance where they are united to be faithful to God Almighty. In the sense, career women are eble to optimize their roles in lifting this tauhid value as well as especially educating their family.
\end{abstract}

Keywords: career woman; Islamic education; digital era; monotheism 


\section{INTRODUCTION}

Family has an important role in education as it is the first growing place of the children where they get the influence from the family members in the most critical phase of education that is in their first years of life (pre-school). Parents, especially mother is the one holding the major role in giving the values of Islamic education to the children.

For a carrier woman, it is certainly not easy to manage the role in a professional manner. Nevertheless, in this digitalization era motherhood is necessary for the educational development of the children. The development of technology and information are like two sides of a coin which give both positive and negative impacts for the children's development. Thus, a mother who works in public spaces should be able to spend more time and attention for the children to choose media and sites that are positive for them.

\section{DISCUSSION}

In order to study and analyze the role of career woman in Islam especially Islamic Education we need to divide it into several aspects. The researcher tried to pay attention to a few problems that almost woman career face while they have to look after their families beside their career. In order to keep Islamic Education for their children as career woman without leaving their duties as wife and mother, especially in a digital era. At the end, how to make career woman balancing between family and her career. The present research aims to answer the following questions: how is the career woman in a Islamic perspective? How is the Islamic education in a digital era? What are the roles of career woman in Islamic education field in a digital era? The present research was done using library resources with analytical and investigative approach.

\section{Career Women in the Islamic Perspective}

The definition of "career woman" according to Kamus Besar Bahasa Indonesia (Department of Education, 2008) is an adult woman who engaged in professional activities (businesses, offices, etc.). The term "career" means "a job or profession for which one is trained and which one intends to follow a part or whole of one's life," or "a job or profession especially one with opportunities of progress." Meanwhile "career woman" (Muri'ah 2011) means "a woman who engaged in professional activities such as business, offices and others with promising skill-based education to gain success in the future ". According to the definition above, it can be concluded that being a career woman is a choice that begins with a person's interest in a specific job. A woman works and engages in a long period of time in order to achieve good performance in wages and status. In the Islamic view, a person having interest in a career should not only focus on such material purposes but also on the impact to 


\section{THE ROLE OF CAREER WOMAN IN ISLAMIC EDUCATION}

the afterlife (ukhrowi).

The decision to become a career woman is influenced by various factors as described by Abdul Halim Abu Syuqqah (1999): 1) the progress and diversity of education including the levels and equity of women and men. This progress grows the capabilities and opportunities for women to cultivate a variety of professional fields; 2) improvement of the services in various sectors opens new needs for the community in which women have to take part in various fields and specialties; 3) progress in the field of transportation which needs to employ women; 4) advancement and diversity of equipment and women's clothing requires experts in matters of trading; 5) household financial problems which require wives to help the family economy; and 6) the case of family discrimination in which some men abandon his responsibilities as head of the family, forcing the wives to work to meet their needs with or without children. Abu Syuqqah sees some internal and external factors that make women difficult to escape the career world. Besides those factors, the development of the era also contributes in making the problem of carrier woman becomes increasingly complex.

In her journey of life, a career woman who has a family will certainly face some problems in running her dual roles. According Bushrah Basiron (2006) at least there are three conflicts of the dual role of women that may occur including the child care, housework, and interaction in the household. However, aside from those problems there are some positive sides of women choosing a career (Aziz, 1994) such as: a) career means to pursue an occupation that generates economic incentives in the form of wages or salaries; b) on the basis of a person's psychological needs (including women), the recognition, respect, and self-actualization makes women more confident; c) from the sociological perspective, women are able to bond in the human interaction; d) from the religious perspective, jobs and careers for women can be valued as a form of religious worship or good deeds. In addition to the positive impacts obtained, it is inevitable that there are some negative impacts of a woman who chooses a career in public spaces. Some of those negative impacts (Junaidi, 2009) include the impact on her, her household, and her children. The job which is routine and formal will cause difficulties for the wife. Other common problems are feeling tired or exhausted because of too much working; feeling hurt in a collision that happened in the workplace; being away from home which is actually her workplace as a real woman; decreasing nature or maternal relationship with the children; and the most worrying is neglecting the domestic affairs, especially the children.

For the children, the absence of mother because she is busy working will lead to the decrease of love and affection. In addition, the absence of mother can make the children 
become spoiled and over demanding. Another harmful impact if a mother could not accompany the children is that it can make the children behave badly, like to argue, oppose, and is easily irritated. Some of the practical steps that need to be done by a mother when there is a gap between her and the children (Asmawati, 2014), among others are: trying to keep calm; asking the children to explain what he exactly felt, thought and expected; conclude the children's feeling with parents' own language (trying to understand the child). Career woman is actually not a new phenomenon in the history of Islamic civilization. In the Prophet era some women are already involved in public spare. Some of them (Shihab, 2007) are: Umm bint Salim Malham as bridal makeup; Siti Khadijah as a merchant and Raithah as a writer. Some verses of the Qur'an mentions about a career woman even though it is not explicitly. However, there are several verses that have been interpreted by potential commentators in accordance with the problems associated with the career (Muri'ah, 2011), such as: Q.S. Al-Ahzab (33) verses 32-33; Q.S At-Tawbah (9) paragraph 71; and Q.S. An-Nahl (16) Paragraph 97. Those several verses of the Qur'an are sufficient evidences proving that Islamic teachings uphold women's rights. Islam gives strong motivation for Muslim women to be able to pursue a career in all fields in accordance with their nature and dignity as women. Islam liberates women from the shackles of ignorance, poverty and slavery. However, Islam guided all man to be free only in accordance with God's guidance.

For women who works outside the house (Muhammad and Abdul, 2005), then it is obligatory for them to maintain these following things: having permission from their guardians either the father or husband to work outside the house; not being together with other men of the opposite sex in the workplace should be framed with the Shari'a; do not show their body (tabarruj) and jewelry off which can cause defamation; do not wear over fragrances when going out of the house. In brief (Nunuk, 2004) a woman should pay attention to her appearance which should be appropriate to Shari'ah. The clothing worn daily in the public space should meet the following criteria (Muri'ah, 2011): clothing that is revealing; clothing that is not flashy, that becomes the pride of the person who wears in front of others; clothing that is not thin; clothing which is loose or not too tight so that the shape of the body is covered; clothing that does not resemble the clothing of men; clothing that is not only an ornament for the beauty which becomes the tool of vanity. Islam gives freedom to the people to design their own fashion as long as it is appropriate to the provisions of the Shari'a.

Although working outside (Muhammad and Abdul, 2005) still a career, woman should make his home as a paradise that can give pleasure to rest and recover the energy. It can only be formed under the auspices of the attention and affection of her husband, and the happiness 
of loving and being loved by her children. That kind of atmosphere will increase the productivity of family and career, so that the best quality (ihsan) and full innovation are achieved.

\section{Islamic Education in the digital era}

Endang Saifuddin Ansari in the book writen by Azyumardi Azra (1999) titled Pendidikan Islam, Tradisi dan Modernisasi Menuju Milenium Baru provides an understanding of Islamic education as "a process of guidance (leadership, demands, proposals) by the educator to the development of the soul (thoughts, feelings, wishes, intuition and so on) and body of the objects learner with certain materials and equipments in order to create certain personality with evaluation in accordance with Islamic teaching. In simple words, Islamic education is a process of adaptation and interaction with the environment actively and productively with the purpose of positive change in one's behavior and activities to achieve the goals of Islamic education in accordance with Islamic guidance.

The purpose of Islamic education according to Abdurrahman Saleh Abdullah in Educational Theory book a Qur'anic Outlook, as quoted by Ahmad Zayadi should include four aspects, namely physical purposes; spiritual and religious purposes; intellectual purposes; and socials ones. Furthermore, according to al-Ibrasiy Athiyah in Ruh al-tarbiyyah wa al-Ta'lim, the core of Islamic education is moral education. This objectives $\backslash$ rest on the words of the Prophet "Innama bu'itstu utammima makarima li al-morality" (in fact I was sent to perfect noble character) (transmitted by Baihaqi). The family as a basic element of society, the smallest element of a State, has a dominant role to achieve the goals of Islamic Education as mentioned above. Countries would be good if each family is living so. The quality of the family is highly dependent on the educational process. According to Ahmad Zayadi (2006) education which is directed, patterned and programmed is that which applied the values of Islam in daily life, especially at home because house is the most strategic place for people to begin the process of effective learning. Education in the family starts with the enforcement of ubudiyah as well as giving the virtues and habituation of worship especially shalat as mentioned in Q.S. Taha verse 132.

Moreover, in the present era where information flows so spaciously, when the good and bad values are in race to influence young souls to follow, it is highly unlikely that the children can be free from the adverse effects of the technological development. What needs to be done by the parents is preparing their children to be able to resist the negative influence of information technology. Here are some guidelines to educate children in the digital era according to a psychologist, Elisabeth Santosa (Lizzie, 2016) who is also the author of 
"Raising Children in the Digital Era": 1) limit the use of gadgets by children; 2) encourage children to do other motorist activity; not only paying attention to the gadget that leads to the passive activity; 3) selectively choose the right media for the child; 4) monitor the children's environment, both in the cyberspace and in the vicinity. Thus, Lizzie suggested that parents monitor their children by becoming friends on social media.

According to the author, the most appropriate parenting that can be applied by parents in today digital era is the concept of Islamic education (monotheism) as described above. Parents should be able to provide exemplary to the children with the teaching of akidah, tauhid, or akhlak since the beginning. Besides, the parents should give understanding to the children with a good sentence to behave with a noble character. Thus, the role of parents is very important in shaping the strength of children's personality; personality which is based on the values of Qur;an, which become the immune to negative influences of the digital era. Therefore, it is expected that the young people of this nation will become strong and tough generation, refreshing the eyes and heart, as well as being leader for the religious people.

\section{Role of career women in Islamic education digital era}

Career woman in Islamic education is inseparable from the three roles: the role as a wife, the role as mother, and the role in community in which those three roles should be run professionally. As a career woman and a housewife, woman should be able to run her function in family (Iklima, 2014) including the economic function (ability to help her husband to earn a living); the protection function (providing protection and comfort to the children); the socialization function (following and being active in activities in the surrounding environment); the educational function (controlling the education of children); religious function (giving religious foundation for the children); the regeneration function (having desire to have children); and the affection function (giving affection and taking care the husband and children's needs).

A wife should constantly strive to establish a harmonious relationship with her husband. One mean to achieve the harmony according to Abu Hudhayfah Ath-Thalibi (2011) is mirroring to the families who have successfully managed to achieve harmony in marriage. It is necessary to learn from the family of the earlier righteous people because it is convinced that they uphold the principles of religion in their lives including in the family life. The family which is shrouded by happiness and harmony will be calm and peaceful for all of the members. The husband will feel at ease in doing the task as head of the household. The wife will feel comfortable in managing domestic affairs and her career. Children feel happy receiving the education from his father and mother. That is the picture of a family filled with 
shades of happiness and harmony.

In the household there are formal relations like the division of role in which the husband as breadwinner and wife as the housekeeper (Sholehudin, 2011), but when the wife works outside the house (career woman) and has other responsibilities outside the household, it will certainly affect the relationship within the family which result in the husband's marital satisfaction. The representation of marital satisfaction according to the theories of Robinson and Blanton (2003), includes several factors, namely: 1) intimacy; 2) commitment; 3) communication; 4) congruence or suitability perception of the strengths and weaknesses of the marriage; and 5) religious beliefs. If some of these factors can be full filled by the couples who are both take career, it is not impossible that happiness, peace and prosperity in the household can be achieved.

Furthermore, Syafiq bin Riza (2016) gives attention to the role of career woman who has had children. Among the rights of children is a good education and guidance to save them from the God's punishment as told in Surah At-Tahrim verse 6. When children get a strong educational foundation from the family environment at an early age, a school environment supports them, and the communities do so, then the success of education will be achieved (Abidin, 2015). The role of mother in educating their children is greater than the role of the father (Syafiq, 2016). Therefore, woman who has lost her husband or being left by him should not be discouraged. Look at Imam Shafi, Imam Bukhari, Sufyan al-Thawri, they are nurtured by their mothers with God's blessing. The first thing that is taught by a mother to her children is to know their God. Teach them that they are the servant of the creator. Then, in the real life if the children want to be happy, there is no other way except His way. The second thing that needs to be taught by a mother to her children is to do the daily prayer. Beside those two things, according to Zainal Abidin (2015) other duties of a mother in educating family are: a) improving religious knowledge; b) completing the means to enrich the religious learning; c) teaching good deeds and worshiping; d) doing muamalah with other human beings; e) preaching with ethics and noble character; f) fostering the love to the family and relatives; g) entertaining and strengthening the faith; h) training for preaching and commanding the good and forbidding the evil; and i) improving the noble qualities.

In this digital era, according to Nina Muthmainnah (2016) a mother needs to be more intensive in the choice of means and media for her children's education. Looking for child-friendly sites such as www.remotivi.or.id is one of the efforts to protect the children from bad influences of the virtual world in which it can no longer be kept out of children's life. Recommendations of any sites or channels which is children-friendly should be checked 
by the parents. Use the conscience to decide if the site is appropriate for children or not. Here are some tips that can be done to protect children from the negative influence of media: (1) observe the way children respond to events or programs in the media; (2) strengthen the families bound; (3) gain deeper insight into media and bullying; (4) educate children to love reading; (5) teach the children to have the Qur'an in their heart so God will guide them to be the future-life saver. Thus, working mothers are not only providing comprehensive facilities for the education of the children but also monitoring their activities, especially those related to the virtual media.

The fulfillment of love and affection and good education for children are things that cannot be ignored by a mother. In addition, a mother is also required to be able to utilize and take the best time to have interaction such us playing with children, especially for working mother. The following are the benefits of playing as stated by dr. Suzy Yusna Goddess (2013): (a) for the development of sensory and motorist development of the children, which are supported by soft and fine motorist skills such as audio visual, feeler, and kinesthetic stimulus; (b) for the intellectual development by providing diverse resources for learning; (c) for the development of the socialization and moral; (d) for the creativity of the children to learn to be creative, to experiment and try out ideas; (e) for their emotions treatment-play will help the children expressing emotions and reduce the pressure on the environment. Thus, it is necessary for a mother to provide time to gather with her children and family therefore the warmth and love as well as the education of the mother as the primary educator for the children can be given. As parent, mother should not only give guidance on what should and should not do by the children, but also give the first example to do or to get away.

In addition to being a religious mother and wife, woman should not also forget her role as a member of society. In social life (Muri'ah, 2011), there are many things as the rights and obligations of each member. Al-Quran as a reference and the basic principles of Islamic societies states that men and women are created in nafs (living entity), in which one does not have a singularity to the other and has the same rights and obligations. The double role of a career woman is not supposed to be the reason to leave her tasks in society. By contributing the ideas and energy in the community, she will be a useful person in the public and she will also have a varied activities. In essence, the relationship between man and woman (hablu minannaas) and the relationship between man and God (hablu minallah) should correspond proportionately.

The women's brain structures which are different from men's make her possible to perform many roles. However, the problem of time management is the most frequently 
encountered by a working woman who is married. When she realized her nature as the woman who is responsible for the development of her children and maintains the trust of her husband, she also faces the demands of the job that sometimes have no compromise. The dilemma requires smart decision to choose the top priority in which it depends on her foresight and wisdom in facing the problems. Another problem is the lack of quality time at home since the most time is already allocated outside.

Indeed, finding the point of balance between staying at home and working is certainly not an easy problem for working woman. Working in an office requires the mother to a dynamic, creative, high mobility which bring her to the flow of life in the public spare, while in the house family as well as household works the mother to spend her time and effort. However, it does not mean that the balance cannot be achieved. The important thing that needs to be owned by a working mother is the consciousness to be always in the equilibrium. Although she should do multirole, career woman must be able to balance the family and work. The word balancing means process, not necessarily been balanced, but there is an awareness to always try to achieve the balance. This awareness is the one that drives the mind and the move of a career woman to always make her "divided" in proportion of family and work.

Therefore, the support and understanding of the husband is essential for a career woman. Gender relations of husband and wife should be understood as a harmonization. They should work together and share a role in educating children, having one vision in caring children with religious education as the main portion. Thus, in addition to harmonization with her husband, support system from her big family, babysitter, and teacher for working mothers is also important. Career woman must establish good communication with the support system. The most important point is synergic partnering of the various parties to support the multirole of woman in order to achieve a balance between work and family (Puspitawati and Rahmawati, 2014).After all, the benefits of the activity of professional working should be for the benefit of the family. Not only the challenge of balancing between household duties and working priorities, other challenges such as discrimination, exploitation and sexual abuse are often experienced by career women. Therefore, according to Meutia Geumala (2014) woman working outside the house should not only bring benefits to the company and the country's income but she can also build strong family in her house, because she is mentally, intellectually and physically healthy because of her job.

\section{CONCLUSION}

Women's brain structures which are different from men enable her to perform many 
roles, both in the domestic and public realm. However, for every woman who chooses to work outside the house should follow some guidelines including: being responsible for the family; guarding her honor; maintaining behavior and promiscuity; and being responsible for every action. As that in Islam there is no obstacle for woman to have career as long as it is done in proper and respectable ways, and she is able to avoid the negative effects and does not forget the nature as woman.

In addition, career woman should not forget also the role as a wife for her husband, a mother for her children and her role in society. Moreover, in the present, the challenge of educating children does not only come from the real world but also from the virtual world. Thus, the role of family, especially the mother is essential to strengthen the personality and intelligence of children including the material, spiritual, and emotional intelligence. The national education system can be endlessly in problem, but do not let the problem comes from the family. By strengthening the role of the family, especially the mother for the children's education, children's intelligence and potential will automatically increase.The double roles in the modern woman's life with all its crowded activities should be circumvented smartly between career and family. Career woman claims to be a partner and a professional in her working place, but she still has to be a good wife and mother to protect her family. Thus, the role and support of her husband and family are necessary for the success of a career . 


\section{REFERENCES}

Abidin, Zainal bin Syamsuddin (2015). 101 Cara Mudah Mendidik Keluarga. Jakarta: Pustaka Imam Bonjol.

Asmawati (2014), Kala Anak Benci Orangtuanya. Majalah Ummi No.10 (XXVI).

Aziz, Abdul bin Abdullah bin Baaz (1994). Fatwa-fatwa Kewanitaan.Jakarta:CV. Firdaus.

Azra, Azyumardi (1999). Pendidikan Islam, Tradisi dan Modernisasi Menuju Milenium Baru. Jakarta: Logos Wacana Ilmu.

Basiron, Bushrah (2006). Wanita Cemerlang. Johor Baru: Universitas Teknologi Malaysia.

Depdikbud, (2008). Kamus Besar Bahasa Indonesia (cet.I edisi 4). Jakarta: Gramedia Pustaka Utama.

Geumala, Meutia (2014). Bekerja antara Manfaat dan Tantangan. Majalah Ummi No.4 (XXVI).

Halim, Abdul Abu Syuqqah (1999). Kebebasan Wanita Jilid 2, Terj. Chairul Hallim, Judul Asli: Tahriri al-Mar"eah fi Asral-Risalah. Jakarta: Gema Insani Press.

Hudzaifah, Abu Ath-Thalibi (2011). 30 Inspirasi Keluarga Harmonis. Solo: Zamzam.

Iklima (2014). E-Journal Ilmu Sosiatri. Peran Wanita Karir dalam Melaksanakan Fungsi Keluarga (Studi Kasus PNS Wanita yang telah Berkeluarga di Balai Kota Bagian Humas dan Protokol Samarinda). Volume 2 Nomor 3, 77-89.

Junaidi (2009). Upaya Mewujudkan Keluarga Sakinah Dalam Keluarga Karir (Studi Pada

Dosen Wanita Fakultas Humaniora dan Budaya Universitas Islam Negeri Maulana Malik Ibrahim Malang ). Tesis. Fakultas Humaniora dan Budaya Universitas Islam Negeri Maulana Malik Ibrahim Malang.

Mahmudah, Siti. Peran Wanita Karier dalam Menciptakan Keluarga Sakinah.

Muhammad, Mahmud Al-Jauhari dan Muhammad Abdul hakim Khayyal (2005). Membangun Keluarga Qureeani: Panduan Untuk Wanita Muslimah. Jakarta: Amzah. Muri'ah, Siti (2011). Nilai-Nilai Pendidikan Islam dan Wanita Karier. Semarang: Rasail Media Group.

Mutmainnah, Nina Armando (2016). Mencari Situs Ramah Anak. Majalah Ummi No.5 (XXVIII).

Nunuk, A. dan P. Murniati (2004). Getar Gender: Buku Kedua. Magelang: Perpustakaan Nasional RI Katalog Dalam Terbitan (KDT).

Puspitawati, Herein dan Sri Rahmawati (2014). Menuju Keseimbangan Dua Dunia. Majalah Ummi No.4 (XXVI).

Robinson, L.C dan Blanton, P. W. (2003). Journal of Family Relations, Material Strengths 
THE ROLE OF CAREER WOMAN IN ISLAMIC EDUCATION

In Enduring Marriages. Volume 42, 38-4.

Santosa, Elisabeth (2016). Era Digital, Orangtua Butuh Ilmu Agar Tak Salah Mendidik Anak, http://edupost.id/parenting/era-digital-orang-tua-butuh-ilmu-agar-tak-salah-mendidikanak/.

Shihab, Muhammad Quraish (2007). Wawasan Al Quran: Tafsir Maudhu'i atas Berbagai Persoalan Umat. Bandung: Mizan Pustaka.

Sholehudin (2011). Peran Wanita Dalam Masyarakat Pedesaan (Studi Partisipasi Isteri Dalam Memenuhi Kebutuhan Dasar Rumah Tangga Petani Di Desa Pohsangit Leres Kecamatan Sumberasih Kabupaten Probolinggo). Skripsi. Fakultas Syari'ah Universitas Islam Negeri Maulana Malik Ibrahim Malang.

Syafiq bin Riza bin Hasan bin Abdul Qadir bin Salim Basalamah (2016). Bersama Keluarga Masuk Surga. Tangerang: STDIIS Press.

Yusna, Suzy Dewi (2013). Mengenal Tumbuh Kembang. Majalah Ummi No.1 (XXV).

Zayadi, Ahmad (2006). Manusia dan Pendidikan, Telaah Teosentris Filosofis. Bandung: Pusat Studi Pesantren dan Madrasah. 